\title{
PROSES PENGELOLAAN DAN PENGOLAHAN LIMBAH CAIR RUMAH SAKIT UMUM DAERAH (RSUD) KOTA BATAM
}

\section{MANAGEMENT AND PROCESSING PROCESSES REGIONAL WASTE OF REGIONAL GENERAL HOSPITALS (RSUD) BATAM CITY}

\author{
Sumalik $^{1}$, Herni Widiyah Nasrul ${ }^{2}$ \\ Program Studi Magister Manajemen Program Pascasarjana Universitas Riau Kepulauan \\ hangsumalik@yahoo.co.id
}

\begin{abstract}
Abstrak
Rumah sakit adalah salah satu unit yang memproduksi kegiatan yang dilakukan di rumah sakit. Aktivitas yang lebih kompleks akan menjadi limbah besar / masalah limbah yang harus diatasi. Sampah atau limbah rumah sakit adalah limbah bahan yang dapat menyebabkan masalah kesehatan lingkungan karena berbagai bahan yang dapat menyebabkan dampak kesehatan dan menyebabkan cedera (Depkes RI 1992). Untuk mendapatkan ulasan tentang proses pengolahan dan pengolahan air limbah di Rumah Sakit Umum Daerah Batam. Jenis penelitian ini menggunakan survei yang menggambarkan analisis analitik dan observasi langsung dengan wawancara mendalam. Berdasarkan hasil penelitian, tingkat pengetahuan tentang pengelolaan limbah cair sangat baik di mana manajer telah dapat menilai penggunaan sistem limbah cair limbah cair rumah sakit. Pengelolaan limbah di Rumah Sakit Umum Daerah Batam telah diklasifikasikan sebagai pendidikan sebagaimana telah sesuai dengan Permenkes RI, 1999. yaitu untuk Rumah Sakit Tipe D (Rumah Sakit Pemerintah). Pengetahuan personil manajemen limbah cair dari Rumah Sakit Umum Kota Batam cukup baik untuk dapat menilai penggunaan sistem pembuangan limbah rumah sakit. Pengelolaan limbah cair di saluran pembuangan limbah Rumah Sakit Umum Kabupaten Batam tidak menggunakan saluran tertutup ketika tidak dipisahkan dari limbah medis dan semua limbah baik dari limbah medis atau limbah non-medis ditampung di pabrik pengolahan air Limbah Air Limbah dari kamar Mandi dibuang ke dalam septik. tank.
\end{abstract}

Kata kunci: Manajemen, Pemrosesan, Limbah Cair

\begin{abstract}
The hospital is one unit that produces activities carried out in the hospital. The more complex activities will be big waste / waste problems to be overcome. Garbage or hospital waste is starting to be realized as a waste material that can cause environmental health problems because of the various materials that can cause health impacts and cause injury (MOHRI 1992). To get a review of the process of waste water treatment and treatment at Batam District General Hospital. This type of research uses a survey that describes analytical analysis and direct observation with in-depth interviews. Based on the research results, the level of knowledge of liquid waste management is very good where the manager has been able to assess the use of sewerage liquid waste hospital systems. Waste management at Batam District General Hospital has been classified with education level personnel as has been in accordance with Permenkes RI, 1999. that is for Type D Hospital (Government Hospital). Knowledge of liquid waste management personnel from Batam City General Hospital is good enough that managers have been able to assess the use of hospital sewage discharge systems. Liquid waste management at Batam District General Hospital sewerage channel does not use closed channels when discharged is not separated from medical waste and all waste either from medical waste or non-medical waste is accommodated at Wastewater Treatment Plant, waste water from room Shower dispose into septic tanks.
\end{abstract}

Keywords: Management, Processing, Liquid Waste

\section{PENDAHULUAN}

Rumah sakit merupakan salah satu unit yang memproduksi limbah atau sampah dari hasil kegiatan yang dilaksanakan di rumah sakit. Semakin kompleks kegiatan pada setiap ruangan atau unit di rumah sakit maka akan besar pula masalah sampah/limbah yang harus 
ditanggulangi. Sampah atau limbah rumah sakit mulai disadari sebagai bahan buangan yang dapat menimbulkan gangguan kesehatan lingkungan karena berbagai bahan yang terkandung didalamnya dapat menimbulkan dampak kesehatan dan menimbulkan cidera (Depkes RI. 1992).

Berdasarkan hasil RapidAssessment tahun 2002 yang dilakukan oleh DitjenP2M-PL Direktorat Penyediaan Air dan Sanitasi yangmelibatkan Dinas Kesehatan Kabupaten dan Kota,menyebutkan bahwa sebanyak 648 rumah sakit daril.476 rumah sakit yang ada, yang memiliki inceneratorbaru 49\% dan yang memiliki Instalasi Pengolahan AirLimbah (IPAL) sebanyak 36\%. Dari jumlah tersebutkualitas limbah cair yang telah melalui prosespengolahan yang memenuhi syarat baru mencapai $52 \%$.

Secara umum penelitian ini bertujuan untuk mengetahuipengelolaan limbah cair di Rumah Sakit. Secarakhusus penelitian ini bertujuan untuk mengetahui prosespenanganan limbah cair serta cara kerja IPAL di RumahSakit, membandingkan hasil analisis kualitas limbahcair yang sudah diolah dengan baku mutu yang telah ditetapkan Pemerintah yaitu Keputusan Menteri Lingkungan Hidup No.Kep.58/MenLH/12/1995.

Pengelolaan terhadap limbah medis merupakan salah satu aspek sanitasi yang harus ditangani dengan baik dan benar, karena selain dapat menimbulkan gangguan terhadap infeksi nosokomial juga dapat menimbulkan gangguan terhadap manusia maupun lingkungan, antara lain : (1) Tempat berkembang biak dan sarang dari pada serangga dan tikus. (2) Dapat menjadi sumber pencemaran tanah, air dan udara. (3) Dapat menjadi sumber dan tempat hidup dari kuman-kuman yang membahayakan kesehatan (Ditjen PPM \& PLP Depkes RI, 1995).

Kesehatan lingkungan suatu rumah sakit serta akan merupakan bagian yang tak terpisahkan dari mutu pelayanan rumah sakit serta akan menunjang proses penyembuhan dan pencegahan infeksi sekunder sehingga apa yang menjadi tujuan masyarakat datang ke rumah sakit akan tercapai.

Dari data yang diperoleh dari Dinas Kesehatan Kota Batam pada tahun 2009 terdapat berapa jumlah rumah sakit yang ada di Kota Batam baik swasta maupun pemerintah terdiri dari rumah sakit swasta 10, pemerintah 1. Dari sejumlah rumah sakit yang ada di Kota Batam ternyata type D ada 1 yang memiliki IPAL.

Berdasarkan survei awal yang dilakukan penulis, di Rumah Sakit Umum Daerah Kota Batam diketahui bahwa sarana proses pengelolaan dan pengolahan limbah cair masih belum 
memenuhi syarat kesehatan.Dari survei tersebut di atas penulis ingin mengetahui kajian proses pengelolaan dan pengolahan limbah cair Rumah Sakit Umum Daerah Kota Batam.

\section{Tujuan Penelitian}

Untuk mendapatkan kajian proses tentang pengelolaan dan pengolahan limbah cair pada Rumah Sakit Umum Daerah Kota Batam.

\section{Kajian pustaka}

Rumah Sakit adalah sebagai sarana pelayanan kesehatan, tempat berkunjungnya orang sakit maupun orang sehat, atau dapat menjadi tempat penularan penyakit serta memungkinkan terjadinya pencemaran lingkungan dan gangguan kesehatan (DepKes, 2004). Kepmenkes RI Nomor : 1204/Menkes/SK/X/2004tentang persyaratan kesehatan lingkungan rumah sakit menyatakan rumah sakit adalah sebagai sarana pelayanan kesehatan untuk pelayanan umum, tempat berkumpulnya orang sakit maupun orang sehat yang memungkinkan terjadinya pencemaran lingkungan, gangguan kesehatan dan atau dapat menjadi tempat penyebab penularan penyakit.

Menurut perumusan WHO yang dikutip Hanafiah dan Amir (1999), pengertian Rumah Sakit adalah suatu keadaan usaha yang menyediakan pemondokan yang memberikan jasa pelayanan medis jangka pendek dan jangka panjang yang terdiri atas tindakan observasi, diagnostic, terapeutik dan rehabilitasi untuk orang-orang yang menderita sakit, terluka dan untuk mereka yang mau melahirkan.

\section{Sanitasi Rumah Sakit}

Sanitasi Rumah Sakit adalah upaya pengawasan berbagai faktor lingkungan fisik, kimiawi dan biologi yang dapat menimbulkan atau mengakibatkan pengaruh buruk pada kesehatan jasmani, rohani dan kesejahteraan sosial bagi petugas, penderita, pengunjung, dan masyarakat disekitar rumah sakit (Departemen Kesehatan RI, 1989 Tentang Komponen Sanitasi Rumah Sakit).

Untuk mengoptimalkan penyehatan lingkungan rumah sakit dari pencemaran limbah yang dihasilkan maka rumah sakit harus mempunyai fasilitas sendiri yang ditetapkan Kepmenkes RI Nomor: 1204/Menkes/SK/X/2004tentang persyaratan kesehatan lingkungan rumah sakit. Fasilitas Pengelolaan Limbah Padat, setiap rumah sakit harus melakukan reduksi limbah dimulai dari sumber dan harus mengelola dan mengawasi penggunaan bahan kimia yang berbahaya, beracun dan setiap peralatan yang digunakan dalam pengelolaan limbah medis mulai dari pengumpulan, pengangkutan, dan pemusnahan harus melalui sertifikasi dari 
pihak yang berwenang.Fasilitas Pembuangan Limbah Cair, limbah cair harus dikumpulkan dalam container yang sesuai dengan karakteristik bahan kimia dan radiologi, volume, dan prosedur penanganan dan penyimpanannya. Rumah Sakit harus memiliki instalasi pengelolaan limbah cair sendiri atau bersama-sama secara kolektif dengan bangunan disekitarnya yang memenuhi persyaratan teknis.

\section{Tenaga Penyehatan Lingkungan Rumah Sakit}

Mengingat upaya penyehatan lingkungan rumah sakit meliputi kegiatan-kegiatan yang sangat kompleks dimana memerlukan penanganan secara lintas program dan lintas sektor serta berdimensi multi disiplin, maka untuk tenaga penyehatan lingkungan rumah sakit sebagai berikut (Permenkes RI, 1999): (a) Untuk Rumah Sakit tipe atau kelas A dan tipe atau kelas B pada Rumah Sakit Pemerintah dan setingkat, pengelola atau direksi rumah sakit dibantu oleh seorang tenaga dengan kualifikasi serendah-rendahnya berijazah S1 dibidang kesehatan lingkungan, teknik penyehatan, kesehatan masyarakat, biologi, teknik kimia, teknik lingkungan dan teknik sipil; (b) Untuk Rumah Sakit tipe atau kelas C pada Rumah Sakit Pemerintah dan yang setingkat, pengelola atau direksi rumah sakit dibantu oleh seorang tenaga dengan kualifikasi serendah-rendahnya berijazah D3 tenaga ahli madya dibidang kesehatan lingkungan, teknik penyehatan, biologi, teknik kimia, teknik lingkungan dan teknik sipil.Untuk Rumah Sakit tipe atau kelas D pada Rumah Sakit Pemerintah dan yang setingkat, pengelola atau direksi rumah sakit dibantu oleh seorang tenaga dengan kualifikasi serendahrendahnya berijazah paramedik dibidang kesehatan lingkungan atau sekolah teknik tingkat menengah.

\section{Klasifikasi Rumah Sakit Tipe A,B,C,D}

Tipe A: Mempunyai lebih dari empat spesialis dasar, ditambah beberapa sub spseialis dan melaksanakan pendidikan dokter, ditambah empat spesialis bedah, spesialis penyakit dalam, spesialis kebidanan dan kandungan, serta spesialis anak. Tipe B: Mempuyai lebih dari empat spesialis dasar dan melaksanakan pendidikan dokter.Tipe C: Mempunyai empat spesialis dasar, tapi tidak melaksanakan pendidikan dokter. Tipe D: Mempunyai lebih dari satu spesialis, tetapi belum mempunyai empat spesialis dasar.

\section{DefinisiLimbah}

Limbah medis sebenarnya meliputi 3 (tiga) jenis yaitu: limbah padat, limbah cair, dan limbah dalam bentuk gas (fame smoke) (Notoatmodjo, 2017). 
Menurut Suriawiria, (2013), limbah dapat juga digolongkan menjadi dua kelompok yaitu:

a. Limbah domestik, yaitu limbah yang sehari-hari dihasilkan akibat kegiatan manusia secara langsung seperti dari kegiatan rumah tangga, pasar, sekolah, pusat keramaian, pemukiman, rumah sakit dan sebagainya.

b. Limbah non demestik, yaitu limbah yang sehari-hari dihasilkan oleh kegiatan manusia secara tidak langsung :dari plastik, industri, pertanian, peternakan, perikanan, kehutanan, transportasi dan sebagainya.

Pembuangan limbah yang berjumlah cukup besar ini paling baik jika dilakukan dengan memilih-milih limbah ke dalam berbagai kategori. Untuk masing-masing kategori diterapkan cara pembuangan limbah yang berbeda. Prinsip umum pembuangan limbah rumah sakit adalah sejauh mungkin menghindari resiko kontaminasi dan trauma (injury). Berdasarkan potensi bahaya yang terkandung didalam limbah medis, maka jenis limbah rumah sakit dapat digolongkan sebagai berikut (Ditjen PPm \& PLP Depkes RI/1997): Limbah Benda Tajam, Limbah Infeksius, Limbah Jaringan Tubuh, Limbah Citotoksis, Limbah Farmasi, Limbah Kimia, Limbah Radio Aktif.

\section{Kategori Limbah Medis}

Limbah medis menurut DepKes RI, 2004,terbagi menjadi 4 (empat) kategori, yaitu: Kategori Aadalah limbah medis yang termasuk dalam kelompok ini adalah perban bekas pakai, sisa lap atau tissue, sisa potongan tubuh manusia dan benda-benda lain yang terkontaminasi serta semua sisa binatang di Laboratorium.Kategori Badalah limbah yang termasuk dalam kelompok ini adalah spuit, jarum suntik bekas, pecahan kaca dan lainlain.Kategori $\mathrm{C}$ adalahLimbah medis yang termasuk dalam kelompok ini adalah bahan-bahan atau sisa obat-obatan dan bahan kimia.Kategori D adalah limbah medis yang termasuk dalam kelompok ini adalah berupa perlak bekas, penampungan urine, tempat penampungan muntah dan bantal bekas yang harus dibuang.

\section{Sumber Limbah Medis}

Rumah Sakit sebagai sarana pelayanan kesehatan memiliki ruangan atau unit kerja dimana sebagian dari ruangan ini dapat menghasilkan limbah atau sampah medis. 


\section{Upaya Pengelolaan Limbah Medis Berbentuk Cair}

\section{Pengumpulan dan Pembuangan Air Limbah}

Pada setiap tempat dimana orang berkumpul akan selalu dihasilkan limbah dan memerlukan pembuangan. Seperti halnya rumah sakit yang merupakan tempat-tempat umum menghasilkan limbah yang lazim disebut limbah rumah sakit atau limbahmedis.Tetapi sebenarnya komposisi limbah pada dasarnya tidak hanya berbeda dengan limbah rumah tangga, bahkan dari segi mikrobiologi sekalipun kecuali limbah yang berasal dari sebagian penyakit.Limbah cair medis adalah semua limbah cair yang berasal dari rumah sakit yang kemungkinan mengandung mikroorganisme dan bahan kimia beracun. Bila bahan-bahan yang terkontaminasi seperti bedpan, dressing, tidak ditangani dengan baik selama pengumpulan maka akandapat terjadi kontaminasi ruangan secara langsung (Depkes RI, 1995).

\section{Sumber dan Sifat-Sifat Air Limbah}

Sumber limbah cair rumah sakit berasal dari ruang kebidanan, operasi, laundry, ruang laboratorium dan dapur.Secara umum air limbah mengandung buangan pasien, sisa makanan dari dapur, limbah loundry, limbah laboratorium berbagai macam bahan kimia baik toksik maupun non toksik dan lain-lain.Umumnya limbah cair rumah sakit bersifat infeksius dan kimia atau toksis, biasanya kandungan organiknya lebih tinggi karena adanya limbah mengandung darah (Depkes RI, 1995).Air buangan atau limbah dapat berasal dari berbagai sumber yang pada umumnya karena hasil perbuatan manusia dan kemajuan teknologi. Beberapa sumber dari air buangan atau limbah antara lain adalah (Kusnoputranto, H. 1986): (a) Air buangan rumah tangga (Domestik waster water), umumnya mempunyai komposisi yang terdiri dari ekskreta, air bekas cucian dapur dan kamar mandi, dimana sebagian besar merupakan bahan organik. (b) Air buangan kotapraja (Municipal wastes water), umumnya berasal dari daerah perkantoran, perdagangan, selokan dan lain-lain. (c) Air buangan industri (Industrial wastes water), umumnya berasal dari berbagai jenis industri akibat proses produksi ini pada umunya lebih sulit dalam pengolahan serta mempunyai variasi yang luas. Zat-zat yang terkandung didalamnya dapat berupa zat pelarut, mineral, logam berat, zat-zat organik, lemak, nitrogen, sulfida, amoniak, garam-garam, zat warna dan lain-lain zat yang bersifat toksik. 


\section{Karakteristik dan Parameter Limbah di Rumah Sakit}

Menurut pendapat Okun dan Ponghis yang dikutip Soeparman dan Soeparmin (2002) berbagai kualitas limbah cair yang penting untuk diketahui adalah bahan padat terlarut (disolved solids), kebutuhan oksigen biokimia (biochemical oxygen demand), kebutuhan oksigen kimiawi (Chemical oxygen demand) dan $p H$. (a) Bahan padat terlarut (TSS), bahan padat terlarut penting diketahui terutama apabila limbah cair akan dipergunakan kembali setelah pengelolaan. (b) Kebutuhan oksigen biokimia (BOD), merupakan ukuran kandungan bahan organik dalam limbah cair dan ditentukan dengan mengukur jumlah oksigen yang diserap oleh akibat adanya mikroorganisme selama satu periode waktu tertentu. Juga merupakan petunjuk dari pengaruh yang diperkirakan terjadi pada badan air penerima berkaitan dengan pengurangan kandungan oksigennya. (c) Kebutuhan oksigen kimiawi (COD), merupakan ukuran persyaratan kebutuhan oksigen limbah cair yang berada dalam kondisi tertentu, yang ditentukan dengan menggunakan suatu oksidan kimiawi. (d) $\mathrm{pH}$, merupakan ukuran keasaman (acidity) atau kebasaan (akalinity) limbah cair, pH menunjukkan perlu atau tidaknya pengolahan pendahuluan untuk mencegah terjadinya gangguan pada proses pengolahan limbah cair.Limbah rumah sakit bisa mengandung bermacam-macam mikroorganisme tergantung pada jenis rumah sakit, tingkat pengolahan yang dilakukan sebelum dibuang.Limbah cair rumah sakit dapat mengandung bahan organik dan anorganik yang umumnya diukur dengan parameter BOD, COD, TSS dan lain-lain (Depkes RI, 1995).

\section{Penampungan dan Pengolahan Limbah Cair Rumah Sakit}

Waste stabilization pond system (Kolam Stabilisasi Air Limbah), Waste oxidation dich treatment system (Kolam Oksidasi air Limbah), Anaerobic filter treatment system, Septic tank.

\section{Pemeliharaan Instalasi Pengolahan Air Limbah}

Enviremment Protection Agency (RPA) telah membuat panduan tentang kebutuhan tenaga agar diperoleh kinerja yang baik dalam pengolahan instalasi pengolahan air limbah, yaitu: (a) Pengawas, seorang yang berpendidikan dalam bidangnya serta mampu berkomunikasi secara lisan, memahami keselamatan dan kesehatan kerja, mampu menganalisa dan mempersentasikan data. (b) Tenaga Pemelihara, seseorang yang menguasai perbaikan mekanis, elektrik dan elektronik. (c) Petugas atau Operator, Petugas diberikan latihan khusus mengenai proses pengangkutan sampah, sedangkan pengawasan dan 
pengolahan sampah rumah sakit di lakukan oleh tenaga sanitasi yang terdidik. Sampah dari setiap unit layanan fungsional rumah sakit di kumpulkan oleh tenaga perawat, khususnya jika berkaitan dengan pemisahan sampah medis dan non medis, sedangkan di ruang lain dapat dilakukan oleh tenaga kebersihan, selain itu petugas pengakut harus dibekali dengan alat pelindung atau pakaian kerja yang memadai (Chandra, 2007).

\section{Pengaruh Pengelolaan Limbah Medis Terhadap Masyarakat dan Lingkungan.}

Dampak positif pengelolaan limbah medis, baik dari pengelolaan limbah rumah sakit akan memberikan dampak positif terhadap kesehatan masyarakat, lingkungan dan rumah sakit itu sendiri, seperti:Meningkatkan pemeliharaan kondisi rumah sakit yang bersih dan rapi, Meningkatkan pengawasan pemantauan dan peningkatan mutu rumah sakit sekaligus akan dapat mencegah penyebaran penyakit (Infeksi nosokomial), Keadaan lingkungan yang saniter serta estetika yang baik akan menimbulkan rasa nyaman bagi pasien, petugas dan pengunjung rumah sakit tersebut, Keadaan lingkungan yang bersih juga mencerminkan keberadaan sosial budaya masyarakat disekitar rumah sakit. Mencegah adanya serangga dan tikus sehingga populasi kepadatan vektor sebagai mata rantai penularan penyakit dapat dikurangi.

\section{Dampak Negatif Pengelolaan Limbah Medis}

Dampak yang ditimbulkan limbah rumah sakit akibat pengelolaannya yang tidak baik atau tidak saniter dapat berupa:Merosotnya mutu lingkungan rumah sakit yang dapat mengganggu dan menimbulkan masalah kesehatan bagi masyarakat yang tinggal dilingkungan rumah sakit maupun masyarakat luar, Limbah medis yang mengandung berbagai macam bahan kimia beracun yang terkena ontaminasi serta benda-benda tajam dapat menimbulkan gangguan kesehatan berupa kecelakaan akibat kerja atau penyakit akibat kerja, Limbah medis yang berupa partikel debu dapat menimbulkan pencemaran udara yang akan menyebabkan kuman penyakit menyebar dan mengkontaminasi peralatan medis ataupun peralatan yang ada, Pengelolaan limbah medis yang kurang baik akan menyebabkan estetika pasien, petugas, pengunjung serta masyarakat sekitar, Limbah cair yang tidak di kelola dengan baik dapat menimbulkan pencemaran terhadap sumber air (permukaan tanah) atau lingkungan dan menjadi media tempat berkembangbiaknya mikroorganisme pathogen, serangga yang dapat menjadi transmisi penyakit terutama kholera, disentri, thypus abdominalis (Kusnoputranto, 2006), Air limbah yang mempunyai sifat fisik, kimiawi, dan 
bakteriologi yang dapat menjadi sumber pengotoran dan menimbulkan bau yang tidak enak serta pemandangan yang tidak menyenangkan, bila tidak dikelola dengan baik.

Berbagai jenis limbah yang dihasilkan di rumah sakit bila tidak dikelola dengan baik dapat mempengaruhi kualitas lingkungan dan komponen-komponen lainnya, secara umum pengaruh limbah medis dapat digolongkan sebagai berikut:

a. Infeksi Silang, Limbah klinis dapat menjadi wahana penyebaran mikroorganisme pembawa penyakit melalui proses infeksi silang baik dari pasien, dari petugas ke pasien, ataupun dari pasien ke petugas, yang dikenal dengan nama infeksi nosokomial.

b. Gangguan Kesehatan, Gangguan kesehatan dapat dikelompokkan menjadi gangguan langsung dan tidak langsung. Gangguan tidak langsung adalah efek yang disebabkan karena langsung dengan limbah tersebut. Misalnya limbah medis beracun, limbah yang dapat melukai tubuh dan limbah yang mengandung kuman pathogen sehingga dapat menimbulkan peyakit.

c. Gangguan Kerja, Petugas dapat terganggu kesehatan dan keselamatan ataupun pekerjaannya apabila tidak dilengkapi dengan alat pelindung diri yang lengkap, antara lain terpapar mikroorganisme pathogen, bahan kimia atau radiasi dengan limbah sebagai media penjalaran.

d. Pencemaran Lingkungan, Pengaruh terhadap lingkungan meliputi kemungkinan terlepasnya ke lapisan air tanah, air permukaan atau udara. Pembuangan yang tidak diwadahi seperti penimbunan terbuka juga menciptakan bahaya terhadap lingkungan.

e. Gangguan Estetika dan Kenyamanan, Penampilan rumah sakit dapat memberikan efek psikologis bagi pemakai jasa, mungkin karena adanya kesan yang kurang baik akibat limbah yang tidak ditangani dengan baik.

\section{Kerangka Konsep}

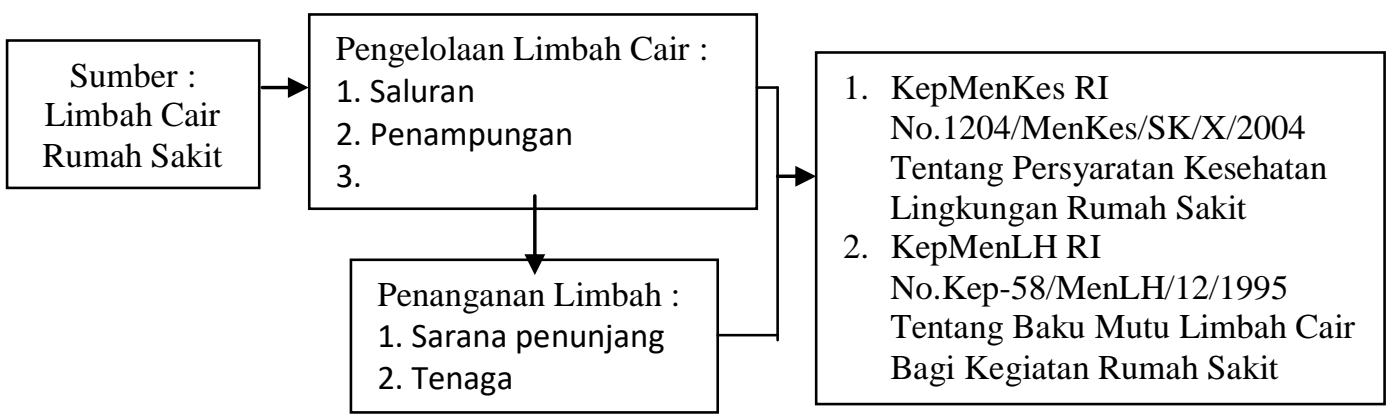

Gambar 1 Kerangka Konsep Penelitian 


\section{METODOLOGI}

\section{Jenis Penelitian}

Jenis penelitian ini menggunakan survei yang bersifat deskriptif analitik atau analisis kualitatif dan observasi langsung dengan wawancara mendalam.

\section{Lokasi Penelitian}

Penelitian ini dilaksanakan pada Rumah Sakit Umum Daerah Kota Batam yang berada di wilayah kerja Dinas Kesehatan Kota Batam yang berada di Jalan Brigjen Katamso, Batu Aji Batam.

\section{Waktu Penelitian}

Waktu penelitian dimulai dengan pengusulan judul penelitian, penyusunan daftar pustaka, persiapan proposal penelitian, merancang kuesioner, konsultasi dengan pembimbing, pelaksanaan penelitian, analisa data sampai dengan penyusunan laporan akhir.Penelitian ini direncanakan selama 2 (dua) bulan, yaitu dari bulan Mei 2010 sampai dengan bulan Juni 2010.

\section{Objek Penelitian}

Yang menjadi objek dalam penelitian ini adalah sistem pengelolaan dan pengolahan limbah di Rumah Sakit Daerah Umum Kota Batam, yaitu limbah cair, sarana penunjang dan mekanisme penanganan limbah cair.

\section{Metode Pengumpulan Data}

\section{Data Primer}

Data primer diperoleh melalui wawancara mendalam pada petugas pengelola limbah dan hasilnya dicatat pada lembar observasi yang dipersiapkan.

\section{Data Sekunder}

Data sekunder diperoleh dari data yang ada di Rumah Sakit Daerah Umum Kota Batam dan dari instansi yang terkait dengan penelitian serta bahan-bahan literatur yang ada.

\section{Definisi Operasional}

Untuk memahami keseluruhan dari penelitian ini, akan dikemukakan defenini operasional dengan tujuan menghindari timbulnya perbedaan dalam pengertian.

1. Sumber limbah rumah sakit adalah limbah padat non medis, limbah medis dan limbah cair yang dihasilkan dari kegiatan rumah sakit.

2. Pengelolaan limbah adalah semua kegiatan yang terlibat dalam penanganan, pengolahan, pemusnahan dan pembuangan limbah (termasuk pengakutan). 
3. Limbah cair adalah semua air buangan yang berasal dari kegiatan rumah sakit.

4. Penampungan adalah tempat penempatan limbah baik untuk limbah padat maupun limbah cair.

5. Pembuangan adalah penempatan limbah rumah sakit ke tempat yang sudah disediakan.

6. Pengolahan adalah cara atau proses yang dilakukan untuk mengurangi karakteristik biologi, kimia dan fisik limbah sehingga bahaya yang ditimbulkan dapat dikurangi.

7. Kepmenkes RI Nomor : 1204/Menkes/SK/X/2004 adalah keputusan menteri kesehatan republik Indonesia tentang persyaratan kesehatan lingkungan rumah sakit.

8. KepmenLH No.Kep-58/MenLH/12/1995 adalah keputusan menteri lingkungan hidup tentang baku mutu limbah cair bagi kegiatan rumah sakit.

9. Sesuai adalah bahwa proses sistem pengolahan limbah rumah sakit sesuai dengan Kepmenkes RI Nomor : 1204/Menkes/SK/X/2004 dan KepmenLH RI Nomor : Kep.58/MenLH/12/1995.

10. Tidak Sesuai adalah bahwa proses sistem pengolahan limbah rumah sakit tidak sesuai dengan Kepmenkes RI Nomor : 1204/Menkes/SK/X/2004 dan KepmenLH Nomor : Kep-58/men LH/12/1995.

\section{Gambaran Umum Rumah Sakit Umum Daerah Kota Batam}

Rumah Sakit Umum Daerah Kota Batam beranjak dari sebuah Puskesmas Rawat Jalan yang dioperasionalkan pada tanggal 8 Oktober 1986 bernama Puskesmas Batu Aji.Pada tahun 1988 statusnya berubah menjadi Puskesmas Rawat Inap dengan 6 tempat tidur. Puskesmas Batu Aji setahap demi setahap berkembang seiring dengan makin beragamnya jenis pelayanan yang ditawarkan dan sesuai dengan disiplin ilmu tenaga medis yang dimiliki Puskesmas Batu Aji, sehingga Puskesmas Batu Aji berubah statusnya menjadi Rumah Sakit Umum Daerah Kota Batam kelas atau type D dengan 52 tempat tidur, milik Pemerintah Kota Batam berdasarkan Surat Keputusan Menteri Kesehatan RI No.779/Menkes/SK/VII/2004 dan disahkan oleh Walikota Batam pada tanggal 11 Oktober 2004.

Pada tanggal 20 Januari 2006 statusnya berubah menjadi salah satu unsur organisasi perangkat daerah yang disahkan melalui Peraturan Daerah Nomor 1 Tahun 2006 tentang Pembentukan Susunan Organisasi dan Tata Kerja Rumah Sakit Umum Daerah. Dengan Perda ini maka Rumah Sakit Umum Daerah Kota Batam menjadi Lembaga Teknis Daerah dalam 
Bidang Pelayanan Kesehatan sebagai Rumah Sakit Umum Daerah Kota Batam dan bertanggung jawab langsung kepada Walikota Batam.

\section{Pengelolaan Limbah Rumah Sakit Umum Daerah Kota Batam}

Tabel 1

Tingkat Pendidikan dalam Pengelolaan Limbah di Rumah Sakit Umum Daerah Kota Batam

\begin{tabular}{|c|l|c|l|c|c|}
\hline No & \multicolumn{1}{|c|}{ Karakteristik } & \multicolumn{2}{|c|}{ Kategori } & Jumlah & $\%$ \\
\hline \multirow{2}{*}{ Pendidikan } & 1 & Tamat SLTA & 2 & 11.76 \\
\cline { 2 - 6 } & 2 & Tamat Akademi/PT & 15 & 88.24 \\
\hline \multicolumn{2}{|l|}{ Jumlah } & 17 & 100 \\
\hline
\end{tabular}

Berdasarkan Tabel 1 di atas dapat diketahui bahwa tingkat pendidikan dalam pengelolaan limbah cair di Rumah Sakit Umum Daerah Kota Batam yang bertype atau jenis C terdiri dari 17 responden yang terlibat dalam pengelolaan limbah cair di rumah sakit yang terdiri dari tamatan SLTA sebanyak 11,76 \% dan tamatan Akademi/PT sebesar 88,24 \%.

Penggunaan Sistem Saluran Pembuangan Limbah Cair Rumah Sakit Umum Daerah Kota Batam

Tabel 2

Penggunaan Sistem Saluran Pembuangan Limbah Cair Rumah Sakit Umum Daerah Kota Batam

\begin{tabular}{|c|l|c|c|}
\hline No & \multicolumn{1}{|c|}{ Jawaban } & Jumlah & $\%$ \\
\hline 1 & Tidak memenuhi syarat & 14 & 82.35 \\
\hline 2 & Kurang memenuhi syarat & 3 & 17.65 \\
\hline \multicolumn{2}{|l|}{ Jumlah } & 17 & 100 \\
\hline
\end{tabular}

Berdasarkan Tabel 2 di atas dapat diketahui bahwa dalam penggunaan sistem saluran pembuangan limbah cair Rumah Sakit Umum Daerah Kota Batam belum yang menjawab memenuhi syarat kesehatan hal dapat dilihat dari 17 responden sebanyak 82,35\% dan yang menjawab kurang atau belum memenuhi syarat kesehatan sebanyak 17,65 \% . 


\section{Apakah Rumah Sakit Harus Memiliki IPAL}

Tabel 3 Rumah Sakit Harus Memiliki IPAL

\begin{tabular}{|c|l|c|c|}
\hline No & \multicolumn{1}{|c|}{ Jawaban } & Jumlah & $\%$ \\
\hline 1 & Harus & 17 & 100 \\
\hline 2 & Tidak & 0 & 0 \\
\hline \multicolumn{2}{|l|}{ Jumlah } & 17 & 100 \\
\hline
\end{tabular}

Berdasarkan Tabel 3 di atas dapat diketahui bahwa tingkat pengetahuan pengelolah limbah cair di Rumah Sakit Umum daerah Kota Batam sudah baik penilaiannya, hal ini dapat dilihat dari 17 responden dan ternyata responden menyatakan bahwa Rumah Sakit Umum Daerah Kota Batam harus memiliki IPAL sebanyak $100 \%$.

\section{Bagaimana Kita Dapat Membedakan Tempat Limbah Medis Dan Non Medis.}

Tabel 4 Bagaimana Kita Dapat Membedakan Tempat Limbah Medis Dan Non Medis

\begin{tabular}{|c|l|c|c|}
\hline No & \multicolumn{1}{|c|}{ Jawaban } & Jumlah & $\%$ \\
\hline 1 & $\begin{array}{l}\text { Tempat pembuangan sampah medis dan non medis } \\
\text { di pisah atau dibedakan }\end{array}$ & 16 & 94.12 \\
\hline 2 & $\begin{array}{l}\text { Tempat pembuangan sampah medis dan non medis } \\
\text { dengan plastik atau label yang berlainan warna }\end{array}$ & 1 & 5.88 \\
\hline \multicolumn{2}{|l|}{ Jumlah } & 17 & 100 \\
\hline
\end{tabular}

Berdasarkan Tabel 4 di atas dapat diketahui bahwa tingkat pengetahuan pengelolah limbah cair di Rumah Sakit Umum Daerah Kota Batam cukup dimana dari 17 responden, 16 responden menjawab sudah dapat membedakan atau memisahkan antara limbah medis dan limbah non medis sebelum dibuang atau dimusnahkan sementara sebanyak 94,12\% dan 1 responden dikatakan cukup baik dimana bisa membedakan atau memisahkan antara limbah medis dan limbah non medis juga dapat memberikan warna antara limbah medis dan limbah non medis sebanyak $5,88 \%$. 


\section{Apakah Kualitas Limbah Cair Rumah Sakit Dilakukan Pemeriksaan.}

Tabel 5 Apakah Kualitas Limbah Cair Rumah Sakit Dilakukan Pemeriksaan

\begin{tabular}{|c|l|c|c|}
\hline No & \multicolumn{1}{|c|}{ Jawaban } & Jumlah & $\%$ \\
\hline 1 & Ya, 6 bulan sekali atau 1 tahun sekali & 10 & 58.82 \\
\hline 2 & Tidak pernah & 2 & 11.77 \\
\hline 3 & Tidak tahu & 5 & 29.41 \\
\hline \multicolumn{2}{|l|}{ Jumlah } & 17 & 100 \\
\hline
\end{tabular}

Berdasarkan Tabel 5 dapat diketahui bahwa pengelolah limbah Rumah Sakit Umum Daerah Kota Batam yang menyatakan bahwa kualitas limbah cair Rumah Sakit Umum Daerah Kota Batam dilakukan pemeriksaan 6 bulan sekali atau 1 tahun sekali sebesar 58,82 $\%$, yang menyatakan tidak pernah dilakukan pemeriksaan sebesar $11,77 \%$ dan yang menyatakan tidak tahu apakah kualitas limbah cair rumah sakit dilakukan pemeriksaan sebesar $29,41 \%$.

\section{Bagaimana Proses Pengolahan Limbah Cair di Rumah Sakit.}

Tabel 6 Bagaimana Proses Pengolahan Limbah Cair di Rumah Sakit

\begin{tabular}{|c|l|c|c|}
\hline No & \multicolumn{1}{|c|}{ Jawaban } & Jumlah & $\%$ \\
\hline 1 & $\begin{array}{l}\text { Limbah cair rumah sakit disalurkan ke bak } \\
\text { penampungan untuk disaring limbahnya dan } \\
\text { kemudian airnya dibuang }\end{array}$ & 12 & 70.59 \\
\hline 2 & Tidak tahu & 5 & 29.41 \\
\hline \multicolumn{2}{|l|}{ Jumlah } & 17 & 100 \\
\hline
\end{tabular}

Berdasarkan Tabel 6 di atas dapat diketahui bahwa pengelolah limbah cair di Rumah Sakit Umum Daerah Kota Batam responden telah mengetahui bagaimana pengelolaan limbah cair rumah sakit, hal ini dapat dilihat dari 17 responden, 12 responden menyatakan limbah cair rumah sakit di salurkan ke bak penampungan untuk disaring limbahnya dan kemudian airnya dibuang sebesar 70,59\% dan sementara 5 responden menyatakan tidak tahu sebesar $29,41 \%$. 
Apakah Ada Dipasang Alat Pengukur Debit Limbah Cair Untuk Mengetahui Debit Harian Limbah Yang Dihasilkan

Tabel 7 Apakah Ada Dipasang Alat Pengukur Debit Limbah Cair Untuk Mengetahui Debit Harian Limbah Yang Dihasilkan

\begin{tabular}{|c|l|c|c|}
\hline No & \multicolumn{1}{|c|}{ Jawaban } & Jumlah & $\%$ \\
\hline 1 & Tidak ada & 16 & 94.12 \\
\hline 2 & Tidak tahu & 1 & 5.88 \\
\hline \multicolumn{2}{|l|}{ Jumlah } & 17 & 100 \\
\hline
\end{tabular}

Berdasarkan Tabel 7 di atas dapat kita diketahui bahwa Rumah Sakit Umum Daerah Kota Batam belum ada atau dipasang alat pengukur debit limbah cair untuk mengetahui debit harian limbah yang dihasilkan, hal ini dapat diketahui dari 17 responden, 16 responden menyatakan tidak ada sebesar 94,12\% dan 1 responden menyatakan tidak tahu sebesar 5,88 $\%$.

\section{Apakah Petugas Dilengkapi Alat Pelindung Diri.}

Tabel 8 Apakah Petugas Dilengkapi Alat Pelindung Diri

\begin{tabular}{|c|l|c|c|}
\hline No & \multicolumn{1}{|c|}{ Jawaban } & Jumlah & $\%$ \\
\hline 1 & Ada dilengkapai sebagian & 15 & 88.24 \\
\hline 2 & Tidak ada & 2 & 11.76 \\
\hline \multicolumn{2}{|l|}{ Jumlah } & 17 & 100 \\
\hline
\end{tabular}

Berdasarkan Tabel 8 di atas dapat diketahui bahwa petugas pengelolah limbah cair Rumah Sakit Umum Daerah Kota Batammenyatakan ada menggunakan alat pelindung diri sebagian sebanyak 15 responden atau 88,24\% dan yang menyatakan tidak ada sebanyak 2 responden atau $11,76 \%$.

\section{Pengelolaan Limbah Cair Rumah Sakit Umum Daerah Kota Batam}

Dari hasil observasi pengelolaan limbah cair Rumah Sakit Umum Daerah Kota Batam dapat dilihat dalam tabel, berikut ini: 
Tabel 9 Observasi Pengelolaan Limbah Cair Rumah Sakit Umum Daerah Kota Batam

\begin{tabular}{|c|c|c|c|}
\hline No & Pengelolaan Limbah Cair & Ya & Tidak \\
\hline 1 & $\begin{array}{l}\text { Saluran pembuangan limbah menggunakan saluran } \\
\text { tertutup dan kedap air }\end{array}$ & & $\mathrm{V}$ \\
\hline 2 & Air limbah mengalir dengan lancar & $\mathrm{V}$ & \\
\hline 3 & Saluran air limbah terpisah dengan saluran air hujan & & $\mathrm{V}$ \\
\hline 4 & Air limbah dari semua ruangan ditampung di IPAL & & $\mathrm{v}$ \\
\hline 5 & Air limbah dari kamar mandi dibuang ke septik tank & $\mathrm{V}$ & \\
\hline 6 & $\begin{array}{l}\text { Apakah dilakukan pengolahan melalui instalasi } \\
\text { pengolahan limbah }\end{array}$ & $\mathrm{v}$ & \\
\hline 7 & $\begin{array}{l}\text { Outlet IPAL diperiksa ke Balai Laboratorium Kesehatan } \\
\text { (BLK) }\end{array}$ & $\mathrm{v}$ & \\
\hline 8 & $\begin{array}{l}\text { Frekuensi pemeriksaan kualitas limbah cair (effluend) } \\
\text { dilakukan minimal } 6 \text { bulan sekali }\end{array}$ & $\mathrm{v}$ & \\
\hline 9 & Kualitas effluend BOD $30 \mathrm{mg} / \mathrm{l}$ & $\mathrm{v}$ & \\
\hline 10 & Kualitas effluend TSS $30 \mathrm{mg} / \mathrm{l}$ & $\mathrm{v}$ & \\
\hline 11 & $\mathrm{pH} 6-9$ & $\mathrm{v}$ & \\
\hline 12 & $\begin{array}{l}\text { Total coliform / } 100 \mathrm{ml} \text { air, kadar maksimum coli adalah } \\
10.000 \mathrm{ml} \text { air }\end{array}$ & $\mathrm{v}$ & \\
\hline 13 & COD $80 \mathrm{mg} / \mathrm{ltr}$ & $\mathrm{V}$ & \\
\hline 14 & $\begin{array}{l}\text { Kualitas effluend yang dibuang ke dalam lingkungan } \\
\text { memenuhi persyaratan Kepmen LH No. } 58 \text { Tahun } 1995\end{array}$ & $\mathrm{v}$ & \\
\hline
\end{tabular}

Berdasarkan Tabel 9 di atas dapat diketahui bahwa Rumah Sakit Umum Daerah Kota Batam saluran pembuangan limbah belum memenuhi syarat kesehatan di karenakan salauran pembuangan limbah cair tidak menggunakan saluran tertutup dan tidak kedap air, tidak terpisah dengan saluran air limbah, sedangkan air limbah dari kamar mandi dibuang ke septik tank. Rumah Sakit Umum Daerah Kota Batam telah melakukan pengolahan air limbah melalui instalsi pengolahan limbah dimana outlet IPAL diperiksakan ke Balai Teknik Kesehatan Lingkungan Dan Pemberantasan Penyakit Menular Kelas I Batam (BTKL-PPM), frekuensi pemeriksaan kualitas limbah cair (effluend) dilakukan minimal 6 bulan sekali, effluend BOD $30 \mathrm{mg} / \mathrm{l}$, kualitas TSS $30 \mathrm{mg} / \mathrm{l}$, sedangkan pH diantara 6 - 9, total coliform per 
$100 \mathrm{ml}$ air, kadar maksimum coli adalah $10.000 \mathrm{ml}$ air, COD $80 \mathrm{mg} / \mathrm{ltr}$ dan kualitas effluend yang dibuang ke dalam lingkungan memenuhi syarat Kepmen LH No. 58 tahun 1995.

\section{PEMBAHASAN}

\section{Pengelolaan Limbah Cair Rumah Sakit Umum Daerah Kota Batam}

Pengelolaan limbah cair di Rumah Sakit Umum Daerah Kota Batam telah mempunyai tenaga dengan klasifikasi tingkat pendidikannya terdiri dari 2 (dua) orang tamatan SLTA dan 15 (lima belas) orang tamatan Perguruan Tinggi, ini berarti Rumah Sakit Umum Daerah Kota Batam dengan demikian ketenagaan pengelolaan limbah cair rumah sakit telah sesuai dengan Permenkes RI, 1999, yaitu untuk Rumah Sakit tipe D (Rumah Sakit Pemerintah) dan yang setingkat, Pengelola atau Direksi Rumah Sakit dibantu oleh seorang tenaga dengan kualifikasi serendah-rendahnya berijazah D3 (tenaga ahli madya) dibidang kesehatan lingkungan, teknik penyehatan, biologi, teknik kimia, teknik lingkungan dan teknik sipil.

Berdasarkan hasil penelitian dapat diketahui tingkat pengetahuan tenaga pengelola limbah cair Rumah Sakit Umum Daerah Kota Batam cukup bagus dimana pengelola sudah dapat menilai dalam penggunaan sistem saluran pembuangan limbah cair rumah sakit. Tidak atau belum memenuhi syarat ini dapat dilihat dari 17 responden atau sekitar $100 \%$ responden menyatakan sistem saluran pembuangan limbah cair rumah sakit, sedangkan 17 responden atau sekitar $100 \%$ menyatakan rumah sakit harus menggunakan IPAL, dan pengelola limbah rumah sakit juga sudah dapat membedakan tempat limbah medis dan non medis harus di bedakan tetapi dari 17 responden hanya 1 responden atau sekita 5,88\% yang menyatakan bahwa tempat limbah medis dan non medis selain dibedakan tempatnya juga harus membedakan warna, dengan membedakan tempat antara limbah medis dan non medis dapat mencegah atau mengurangi akibat-akibat buruk dari limbah medis sesuai dengan persyaratan Kepmenkes RI Nomor: 1204/Menkes/SK/X/2004 tentang persyaratan kesehatan lingkungan rumah sakit.

Sementara untuk kualitas limbah cair dari 17 responden 7 atau sekitar 41,18\% tidak tahu apakah kualitas limbah cair rumah sakit diperiksa atau tidak sedangkan kualitas limbah (effluend rumah sakit yang akan dibuang ke badan air atau lingkungan harus memenuhi persyaratan baku mutu effluend sesuai KepMenLH RI Nomor : Kep-58/MenLH/12/1995 tentang Baku Mutu Limbah Cair Bagi Kegiatan Rumah Sakit, untuk mendapatakan kualitas limbah (effluend) yang sesuai dengan keputusan Menteri Lingkungan Hidup limbah cair perlu dilakukan proses pengelolaan dari 17 responden atau sekitar 70,59 \% menyatakan limbah cair 
Rumah Sakit Umum Daerah Kota Batam disalurkan ke bak penampungan untuk disaring limbahnya dan kemudian airnya dibuang, dalam hal ini Rumah Sakit Umum Daerah Kota Batam telah melakukan proses pengelolaan limbah sebelum limbah disalurkan ke badan air atau ke lingkungan sekitarnya, sedangkan untuk mengetahui debit air limbah cair yang dihasilkan perlu dipasang alat pengukur debit air limbah hal ini untuk mengetahui berapa banyak limbah cair yang dihasilkan dalam satu hari, kegunaan dari pengkuran debit air limbah memudahkan dalam proses pengolahan air limbah sehingga akhir dari proses didapat kualitas limbah yang sesuai dengan baku mutu air limbah menurut KepMenLH RI Nomor : Kep-58/MenLH/12/1995 tentang Baku Mutu Limbah Cair Bagi Kegiatan Rumah Sakit yaitu kualitas limbah rumah sakit yang akan dibuang ke badan air atau lingkungan harus memenuhi persyaratan baku mutu effluend. Sedangkan bahaya yang ditimbulkan limbah dengan aktivitas rendah mungkin terjadi karena kontaminasi permukaan luar container atau karena cara serta durasi penyimpanan limbah tidak layak, tenaga layanan kesehatan atau tenaga kebersihan dan penanganan limbah yang terpajan radioaktif merupakan kelompok yang beresiko (Pruss. A, 2005) sedangkan petugas pengelola limbah cair di Rumah Sakit Umum Daerah Kota Batam ada menggunakan alat pelindung diri dalam penanganan limbah cair di rumah sakit.

\section{Observasi}

Pengelolaan limbah cair di Rumah Sakit Umum Daerah Kota Batam saluran pembuangan limbah tidak menggunakan saluran tertutup sehingga air hujan ketika turun tidak terpisah dengan limbah cair rumah sakit ditampung di Instalasi Pengolahan Air Limbah, air limbah dari kamar mandi dibuang ke septik tank sementara limbah medis cair dari rumah sakit harus dikumpulkan dalam container yang sesuai dengan karakteristik bahan kimia dan radioligi, volume, dan prosedur penanganan dan penyimpanan, saluran pembuangan limbah harus menggunakan sistem saluran tertutup, kedap air dan limbah mengalir dengan lancar, serta terpisah dengan saluran air hujan, disamping itu rumah sakit harus memiliki instalasi pengolahan limbah cair sendiri atau bersama-sama secara kolektif dengan bangunan disekitarnya yang memenuhi persyaratan teknis, apabila belum ada atau tidak terjangkau sistem pengolahan air limbah perkotaan masih bisa dapat digunakan, pemasangan alat pengukur debit limbah cair untuk mengetahui debit harian limbah yang dihasilkan perlu dipasang dan untuk air limbah dari laboratorium harus diolah di Instalasi Pengolahan Air Limbah (IPAL), bila tidak mempunyai IPAL harus dikelola sesuai ketentuan yang berlaku 
melalui kerjsama dengan pihak lain atau yang berwenang seperti Balai Teknik Kesehatan Lingkungan Dan Pemberantasan Penyakit Menular Kelas I Batam (BTKL-PPM) yang telah dilakukan oleh Rumah Sakit Umum Daerah Kota Batam, frekuensi pemeriksaan kualitas limbah cair dilakukan setiap 6 bulan sekali sesuai ketentuan yang berlaku.

Rumah Sakit Umum Daerah Kota Batam telah menggunakan IPAL dan dapat hasil $\mathrm{pH}$ diantara 6-9, kualitas effluend BOD 30 mg/l, dan kualitas TSS 30 mg/l, Total Ciliform per $100 \mathrm{ml}$ air, kadar maksimum coli adalah $10.000 \mathrm{ml}$ air, limbah cair ini telah menunjukkan bahwa hal ini sesuai dengan Kep KepMenLH RI Nomor : Kep-58/MenLH/12/1995 tentang Baku Mutu Limbah Cair Bagi Kegiatan Rumah Sakit.

Limbah rumah sakit bisa mengandung bermacam-macam mikro organisme tergantung pada jenis rumah sakit, tingkat pengolahan yang dilakukan sebelum dibuang.Limbah cair rumah sakit dapat mengandung bahan organik dan anorganik yang umumnya diukur dengan parameter BOD, COD, TSS dan lain-lain (Depkes RI, 1995).

Apabila rumah sakit memiliki unit pengolahan sendiri, maka kandungan ini harus dimonitor untuk menilai hasil kerja unit pengolahan.Berbagai bakteri indikator perlu diperiksa setelah desinfeksi. Parameter yang lazim digunakan untuk pemeriksaan air limbah rumah sakit antara lain harus sesuai dengan KepMenLH RI Nomor : Kep-58/MenLH/12/1995 tentang Baku Mutu Limbah Cair Bagi Kegiatan Rumah Sakit.

\section{KESIMPULAN DAN SARAN}

\section{Kesimpulan}

Pengelola limbah cair di Rumah Sakit Umum Daerah Kota Batam telah mempunyai tenaga dengan klasifikasi tingkat pendidikannya telah sesuai dengan Permenkes RI, 1999.yaitu untuk Rumah Sakit Tipe D (Rumah Sakit Pemerintah).Pengetahuan tenaga pengelola limbah cair Rumah Sakit Umum Daerah Kota Batam cukup bagus dimana pengelola sudah dapat menilai dalam penggunaan sistem saluran pembuangan limbah cair rumah sakit.Pengelolaan limbah cair di Rumah Sakit Umum Daerah Kota Batam saluran pembuangan limbah tidak menggunakan saluran tertutup sehingga limbah air hujan ketika turun tidak terpisah dengan limbah medis dan semua limbah baik dari limbah medis maupun limbah non medis ditampung di Instalasi Pengolahan Air Limbah, air limbah dari kamar mandi buang ke septik tank. 


\section{Saran}

Disarankan BPLH Kota dan Dinas Kesehatan Kota Batam memotivasi Rumah Sakit Umum Daerah Batam dalam pengelolaan limbah cair medis rumah sakit sesuai dengan Kepmenkes RI Nomor: 1204/Menkes/SK/X/2004 tentang persyaratan kesehatan lingkungan rumah sakit.Pengelolah limbah cair medis Rumah Sakit Umum Daerah Kota Batam hendaknya disamping dapat membedakan antara limbah cair medis dan non medis hendaknya dapat juga menggunakan logo atau warna tertentu untuk jenis limbah yang berbeda seperti untuk limbah medis memakai warna merah dan sebagainya.Untuk saluran limbah medis sistem saluranyan harus tertutup agar terpisah dari limbah air hujan dan limbah lain-lainya dan limbah dari kamar mandi seharusnya dibuatkan tempat penampungan sendiri.IPAL harus dikelola sesuai ketentuan yang berlaku melalui kerjsama dengan pihak lain atau yang berwenang seperti BTKL yang telah dilakukan oleh Rumah Sakit Umum Daerah Kota Batam, frekuensi pemeriksaan kualitas limbah cair terolah dilakukan setiap bulan sekali untuk swapantau dan minimal 6 bulan sekali untuk uji petik sesuai ketentuan yang berlaku.

\section{REFERENSI}

Achmad. U. F. (2015). Manajemen Penyakit Berbasis Wilayah. Jakarta: Kompas.

Azwar. (2010). Pedoman Kesehatan Masyarakat Dalam Desentralisasi Pembangunan Kesehatan. Jakarta.

Chandra. (2007). Pengantar Kesehatan Lingkungan. Jakarta: cetakan I penerbit EGC.

Departemen Kesehatan Republik Indonesia.(1989).Tentang Komponen Sanitasi Rumah Sakit. Jakarta.

Departemen Kesehatan Republik Indonesia. (2012).Kesehatan. Jakarta.

Departemen Kesehatan Republik Indonesia. (2005). Pedoman Penatalaksanaan Pengelolaan

Limbah Padat dan Limbah Cair di Rumah Sakit. Jakarta.

Dirjen PPM \& PLP.(2005). Materi Pelatihan PenyehatanAir. Jakarta.

Deputi IV Bidang Pengelolaan B3 Dan Limbah B3 Kementerian Negara Lingkungan Hidup. (2009). Pedoman - SOP Evaluasi Penerbitan Perizinan Pengelolaan Limbah B3. Jakarta.

Keputusan Menteri Negara Lingkungan Hidup Nomor KEP-58/MENLH/12/1995 Tentang Baku Mutu Limbah Cair Bagi Kegiatan Rumah Sakit. (2002). Jakarta: Kementerian Lingkungan Hidup. 
Kementerian Lingkungan Hidup. (2006).Himpunan Peraturan Perundang-Undangan Di Bidang Pengelolaan Lingkungan Hidup. Jakarta.

Notoatmojo, S. (2005). Metodologi Penelitian Kesehatan. Jakarta: Rineka Cipta.

Peraturan Menteri Negara Lingkungan Hidup Nomor 18 Tahun 2009 Tentang Tata Cara Perizinan Pengelolaan Limbah Bahan Berbahaya Dan Beracun. (2009). Jakarta.

Pruss. (2005). Pengelolaan aman Limbah Layanan Kesehatan.Jakarta.

Sujudi. (2003). Lokarkarya Penangan Limbah Medis Tajam Pada Pelayanan Kesehatan Dasar (PKD). Yogyakarta. 